\title{
The Effectiveness of De Bono's Six Thinking Hats Technique in the Development of Critical Thinking and Numerical Sense in Mathematics Education in Oman
}

\author{
Abdelkader Mohamed Abdelkader Elsayed, College of Arts and Applied Science, Dhofar University, Salalah, \\ Oman, abdelkader_elsaayed@du.edu.om \\ Rasha Elsayed Sabry Abbas, College of Education, Ain Shams University, Cairo, Egypt, dr.rasha123@yahoo.com \\ *Corresponding Author
}

\begin{abstract}
The primary goal of education is to develop the students' minds, including critical thinking and numerical sense. To develop these skills, a teacher is well-advised to use modern techniques and one of these is De Bono's Six Thinking Hats technique. We hypothesized that De Bono's technique applied to teaching math would substantially increase the skills of students. Participants in the experimental group $(N=34)$ received a treatment based upon the Six Thinking Hats technique, and participants in the control group $(N$ $=35$ ) received an alternative treatment. Data were analyzed using means, standard deviations, $t$-tests, and effect sizes. Skills increased much more for the experimental group. It is clear that the Six Thinking Hats technique was highly effective in developing math skills, and various reasons were discussed. It is recommended to consider extending the use of the Six Hats technique to the teaching of all the mathematics courses in secondary education, and focus on preparing activities that enable students to practice critical thinking skills and numerical sense.
\end{abstract}

Keywords: De Bono, Thinking Hats, Critical Thinking, Numerical Sense, Dhofar Region; Oman Received: $12.11 .2020 \quad$ Accepted: 08.12.2020 $\quad$ Published: 15.01.2021

\section{INTRODUCTION}

The primary goal of education is to develop the students' minds, enabling them to acquire the ability to conclude, imagine, invent, critique, and create (Pape, at al., 2003). To achieve this goal, we should focus on developing thinking patterns and refining the learner's abilities to develop, organize, store, and employ the methods of mental processing of acquired knowledge (Alsayyed \& Ahmad, 2009; Drijvers, et al., 2019). Thinking is one of the key goals of education in different stages of the learning process (NCTM, 2014; Pape, at al., 2003). All countries have developed curricula and Techniques so that students may learn methods of thinking to contribute to developing students' minds so that they can face the local and global challenges in different walks of life (Doerr, 2006; Drijvers, et al., 2019; Irwin \& Britt, 2005; Rushton, 2006; ). Critical thinking is one of the most important types of thinking because it helps learners to assess the quality of information and ideas they encounter (Liang \& Fung, 2019; Klein, et al., 2010) . Numerical sense is related to both critical thinking and mathematics simultaneously (El Mouhayar, 2018), as it reflects the student's ability to understand the meanings of numbers and appreciation of these numbers, and the creation of relationships between numbers and their use in a variety of situations (Palatnik \& Koichu, 2017; Wagner \& Davis, 2010).

As critical thinking and numerical sense are essential goals for education, a teacher is well-advised to use modern techniques that develop these for students (Chrysostomou, et al., 2013; Doerr, 2006; Palatnik \& Koichu, 2017). One of these techniques is De Bono's Six Thinking Hats technique (Gocmen \& Coskun, 2019), which aims to simplify thinking and increase its effectiveness, and allows the learner to move from one thought pattern to another. This technique consists of six types of thinking, symbolized by six hats, each with a different color (Nofal, 2009). In the present study, we apply the Six Thinking Hats techniques in teaching mathematics to primary school students in Oman and test its effectiveness in developing critical thinking and numerical sense.

\section{Critical Thinking}

Critical thinking is a mental process that learners perform when they face a specific problem, through which they can practice a series of successive mental skills in a logical and organized way (Liang \& Fung, 2020). These 
skills enable them to judge and evaluate things related to the problem. In this way, they can not only solve the present, specific problem, but they also benefit when they face future problems (Doerr, 2006; Drijvers, et al., 2019; Kwan \& Wong, 2015; Liang \& Fung, 2019). Though there are different opinions and viewpoints concerning specifying the critical thinking skills (Alosaimi, 2013; Facione, 2011; Fisher, 2011; Halpern, 1996; Kwan \& Wong, 2015; Liang \& Fung, 2020); Volpentesta, et, al. (2008), and Zoller and Mura (2000) specify these skills as follows:

(A) Knowledge of assumptions and postulates: These are the individuals' convictions about a given topic, where they can examine the incidents and data in such a topic so that they can judge that certain assumptions are likely or unlikely, according to the accurate examination of the given incidents.

(B) Interpretation: It enables individuals to estimate evidence and distinguish between data and justified and unjustified instructions to reach the likely and justified conclusion. It is also represented in individuals' ability to reasonably draw a specific conclusion from assumed facts.

(C) Deriving: It is individuals' judgment on whether a particular conclusion is drawn from certain premises. It is represented in individuals' ability to know and specify relations between specific incidents. In light of this knowledge, they can determine whether a particular conclusion is derived from such premises, irrespective of the validity of these incidents.

(D) Deduction: In this process, the individuals reach a specific conclusion in light of given data, and information is represented in their ability to specify whether a certain conclusion is right or wrong according to their relatedness to the incidents or data they are offered.

(E) Estimating arguments and discussions: This means that individuals can distinguish between strong and weak arguments related to the topic. It is represented in individuals' ability to specify and realize the critical aspects directly related to the topic and distinguish between strong and weak aspects.

\section{Numerical Sense}

Dehaene (1997) popularized the term 'number sense' in his book The Number Sense, in which the term referred to the "sense of approximate numerical magnitudes" (Freitas \& Sinclair, 2016). The term is now used much more broadly as a catchall phrase for arithmetic skills, particularly in the pre-k to grade 2 curricula (NCTM, 2014). Numerical sense is the ability to understand the meaning of mathematical concepts (Badawi, 2007; Yang, 2019), to apply mathematical operations, and to recognize and name number symbols (Pinto et al., 2016), numerical relational and counting skills (Purpura \& Reid, 2016), basic addition and subtraction skills (Jordan et al., 2010) and use these skills through the application of logical thinking methods (Aunio et al., 2019). Achieving numerical sense is a fundamental goal of teaching mathematics (NCTM, 2014). Different authors come up with different skills that make up numerical sense. According to Badawi (2007); Nieder \& Dehaene (2009); Palatnik \& Koichu (2017), and Yang (2019) numerical sense consists of seven skills, namely:

1. Knowing the different uses of numbers.

2. Characterizing the suitability of numbers in some situations or not in other situations.

3. Linking numbers with their different amounts to the things, events, and real situations in reality.

4. Guessing the outputs of calculations approximately to reach an approximate answer to the sums or access to a reasonable guess concerning assessment.

5. Relations between the numbers and measurements.

6. Discriminating relations between the group and the partial and between the part and the whole.

7. Understanding phrases that establish mathematical relationships such as greater than, less than, and others.

Abuasta (2011) and Chrysostomou, et al. (2013) identified numerical sense skills in kindergarten as follows:

1. Realizing the relative impact of operations on numbers, which means that the student understands the meaning of the arithmetic operation and determines the effect of each operation on the numbers forming the sentence.

2. Understanding the properties of mathematical operations related to numbers, which is the ability of the student to employ the properties of arithmetic operations on numbers.

3. Rename numbers, which means the student's ability to rewrite a number in the form of addition or subtraction of two other numbers.

Carole et al. (1993) and El Mouhayar (2018) report numerical sense as consisting of six skills, namely:

1. Realizing the different uses of numbers such as determining quantum, name, measurement, and position.

2. Determining appropriate numbers for various positions. 
3. Linking numbers with the number of different topics, events, and real-world situations

4. Estimating the outputs of calculations.

5. Determining the relations among numbers and measurements.

6. Discriminating relations between the group and the partial and also between the part and the whole. In line with the skills described above, in the present study, we choose three skills that we used for sixthgrade students:

(A) Recognize the relative impact of operations on numbers:

It means that each of the mathematical operations, such as addition and subtraction, has a special effect on the outcome of this operation, regardless of its type, as well as on the numbers involved in that process.

(B) Estimate the results of mathematical operations:

It means finding an estimated value for the result of the mathematical operation without performing the operation in the usual ways using paper and pen, such as discovering errors in the results of some mathematical operations without implementing them.

(C) Determine the relationships between macro (comprehensive) and micro-groups:

It means determining the type of relationship between groups, such as the relationship of containment, intersection, affiliation, and sub-group.

\section{Six Thinking Hats Technique}

De Bono used his Six Thinking Hats as a technique to look at the making of decisions using different points of view, but the technique is also applicable to other domains (Hollenbeck, 2003; Serrat, 2017). The six hats have different colors, including the color white (information and facts), red (emotions and feelings), black (negative aspects), yellow (positive aspects), blue (assessing things and prioritizing), and green (new ideas) (Gocmen \& Coskun, 2019). De Bono believed that when individuals think, they usually employ all different types of thinking simultaneously, which leads to confusion, misunderstanding, and lack of concern and rationality, which results in subjective conclusions (Serrat, 2017). So, De Bono designed the Six Thinking Hats technique to help individuals think rationally and realistically, making them more productive (Kharrazah, 2016).

The Six Thinking Hats technique is one of the most important educational techniques used to improve and teach thinking, making the teachers and learners more active and effective (Tamura \& Furukawa, 2007). The Six Thinking Hats technique aims to enable students to use only one pattern of thinking at one time by choosing the color of each hat in a way that matches the nature and quality of its thinking (Serrat, 2017). The white hat is a symbol of neutral thinking, the red hat is a symbol of expression of emotions and feelings, the black one symbolizes negativity, the yellow one is a symbol of optimism and constructive thinking and brightness, the green hat symbolizes creativity and generation of new ideas, and finally the blue one represents the organization of thinking and reaching learning outcomes (Habib, 2013; Gocmen \& Coskun, 2019; Serrat, 2017).

Several studies in education focused on this approach. For instance, Abdrabbu (2017) conducted a study to measure the relative effectiveness of the Six Thinking Hats technique and Self-Regulated Learning on the development of lateral thinking and achievement motivation in the teaching of mathematics among thirdgrade students. The researcher used the experimental method, with a study sample that consisted of 150 students. The researcher used a test of lateral thinking and a geometry achievement test. The most important results of the study were the effectiveness of self-organized learning in the development of achievement and the effectiveness of the Six Thinking Hats in the development of lateral thinking. Additional relevant educational studies were carried out by Ahmed (2016), Alsaidi (2015), Alakka (2014), Abdullatif et al. (2014), Gocmen and Coskun (2019), Habib (2013), Hilal (2013), and Tamura \& Furukawa (2007).

\section{Research hypotheses}

We set up a study where we tested what the effects of the use of De Bono's technique were in education. We used an experimental study with a treatment group and a control group. We tested the following two hypotheses:

1) There is a substantial difference between the mean posttest scores on a critical thinking test of the experimental group and the control group in favor of the experimental group.

2) There is a substantial difference between the mean posttest scores on a numerical sense test of the experimental group and the control group in favor of the experimental group. 


\section{METHOD}

We employed a classical experimental design where two groups of research participants were randomly assigned to the experimental condition and the control condition. The participants in the experimental group received a treatment based upon the Six Thinking Hats technique, and the participants in the control group did receive an alternative treatment. We then checked whether the experimental group showed the strongest improvements on two outcome variables.

\section{Sample of the Study}

The research sample was comprised of 69 students in the sixth grade from two schools in the Salalah state of the Dhofar region in the sultanate of Oman: Aisha bint Abi Bakr school and Manbaa Alhekma school. The experimental group consisted of 34 students from Aisha bent Abi Bakr school, and the control group consisted of 35 students from Manba Alhekma school.

The institutional review board of the university involved approved this study. All parents of the research participants signed written informed consent before participation. All procedures involved human participants and they were in accordance with the ethical standards of the university involved and with the 1964 Helsinki Declaration and its later amendments.

\section{Study Materials and Tools}

\section{Teacher's guide based upon the Six Thinking Hats Technique.}

The author constructed a guide for mathematics teachers, explaining the teaching of the third and fourth units included in the sixth-grade math textbook (circle and geometric construction) using the Six Thinking Hats technique. This guide includes the objectives of the units, learning aspects, critical thinking skills, numerical sense skills, teaching aids and activities, teaching steps, and evaluation. The appropriateness of the guide was checked by presenting it to eight mathematics teaching experts and six primary mathematics teachers, and it was modified according to their suggestions.

\section{Critical Thinking Test}

The author developed a test to measure the students' critical thinking skills. The test of critical thinking in math was prepared to measure the level of possession of $6^{\text {th }}$-grade students' critical thinking skills. The first version of the test consisted of 25 questions related to the five critical thinking skills in math (knowledge of assumptions and postulates, interpretation, deriving, deduction, and estimating arguments and discussions) depending on the relative importance of each skill and the number of sub-skills. So, the test consisted of five multiple-choice questions for each of the five skills. To ensure validity, this test was presented to ten faculty members specialized in curriculum development, teaching methods in math, and some items were deleted and modified based on their suggestions. The agreement between the specialists was high at $85 \%$. To verify the reliability of the final version of the test, which consisted of 20 questions, it was taken by a sample of $N=45$ $6^{\text {th }}$-grade students of Khalid ibn al-Walid school in Salalah, Oman. To gauge the reliability of the test, we computed Guttman's equation, which yielded a value of 0.86 , which means the test has a high level of reliability. Each question yielded one point for the right answer and zero points for the false one. So, the maximum score on the test was 20 , and the minimum score was 0 . The maximum amount of time allowed for the test was 50 minutes.

\section{Numerical Sense Test}

The author developed a test to measure the level of possession of $6^{\text {th }}$-grade students' numerical sense. The first version of the test consisted of 21 questions related to the three numerical senses (recognize the relative impact of operations on numbers, estimate the results of mathematical operations, and determine the relationships between macro [comprehensive] and micro-groups), depending on the relative importance of each skill and the number of sub-skills. So, the test consisted of seven multiple-choice questions for each of the three skills. To ensure the validity of the test, it was presented to the same ten specialists mentioned above, and some items were deleted and modified based on their suggestions. Again, the agreement between the specialists was high at $88 \%$. To gauge the reliability of the final version of the test, which consisted of 20 questions, it was taken by the same sample that also took the critical thinking in math test described above. The value of Cronbach's alpha was 0.84 , indicating that the test has a high level of reliability. Each question yielded one point for the right critical thinking and numerical sense in mathematics education in oman 
answer and zero points for the false one. So, the maximum score on the test was 20 , and the minimum score was 0 . The maximum amount of time allowed for the test was 40 minutes.

\section{Variables}

The independent variable of the current study is the teaching technique employed, which is either the Six Hats technique or a traditional technique. The dependent variables are critical thinking and numerical sense. Table 1 shows these variables.

Table 1. The independent and dependent variables of the study

\begin{tabular}{|l|l|l|}
\hline \hline \multicolumn{1}{|c|}{ Independent Variables } & Six Hats technique & Traditional technique \\
\hline Dependent Variables & A1 & A2 \\
\hline Nuitical Thinking & A3 & A4 \\
\hline
\end{tabular}

Note. A1: Critical thinking for the group taught by the Six Hats technique (experimental group)

A2: Critical thinking for the group taught by a traditional technique (control group)

A3: Numerical sense for the group taught by the Six Hats technique (experimental group)

A4: Numerical sense for the group taught by a traditional technique (control group)

\section{Study Design}

The study design is described in Table 2 .

Table 2. The treatment and performance variables of the study

\begin{tabular}{|l|l|l|l|}
\hline A1 & S1 & M1 & M2 \\
\hline A2 & S2 & M1 & M2 \\
\hline A3 & S3 & M1 & M2 \\
\hline A4 & S4 & M1 & M2 \\
\hline
\end{tabular}

Note. S1: Treatment for the experimental group (critical thinking - six hats technique)

S2: Treatment for the control group (critical thinking - traditional technique)

S3: Treatment for the experimental group (numerical sense - six hats technique)

S4: Treatment for the control group (numerical sense - traditional technique)

M1: Performance on the pretest of critical thinking, and numerical sense

M2: Performance on the posttest of critical thinking, and numerical sense

\section{Experimental Treatment}

The study was carried out for 12 weeks in a class that met four times a week, so there were 48 lessons in all. The experimental and control groups were pretested, and then the experimental group was taught the third and fourth units included in the sixth-grade math textbook (circle and geometric construction) by the mathematics teacher at Aisha bent Abi Bakr school (Mrs. Fatima Al-Mashani) using the Six Hats technique. Meanwhile, the control group was taught the same units by the mathematics teacher at Manba Alhekma school (Mrs. Somiya Al-Bathary) using a traditional teaching method. At the end of the treatment period, the students of the two groups were post-tested.

\section{Statistical Analyses}

Data were analyzed using mean, standard division, T-test, $\eta 2$, and effect size using SPSS version 22 . In this study, we employ a pretest-posttest control-group design, and the central measurement is the effectiveness of the Six Hats technique. We assume the groups in the two schools have comparable levels of, respectively, critical thinking skills and number sense, as the two groups were randomly assigned to the control condition and the experimental condition; therefore, a good measure of the effectiveness of the Six Hats technique is the difference between the posttest score of the experimental group and the posttest score of the control group. It is expected that the experimental group has a larger posttest score than the control group. To arrive at an effect size value, this difference score needs to be divided by the best standard deviation available. Following Grissom and Kim (2012, pp. 90-92), we use the pooled $S D$ of the pretest for both the control and the experimental group. 
Grissom and Kim discourage pooling the four $S D$ s of both pretest and posttest for both the control group and the experimental group, as treatment generally increases variability, leading to values of $S D$ for the posttests for the control and experimental group that differ from each other.

\section{RESULTS}

The first hypothesis is that the experimental group has higher levels of critical thinking than the control group at the end of the experiment. Table 3 shows that the hypothesis is strongly confirmed: there are huge differences between the groups on all the individual thinking skills and the total score; the values of the effect size vary from 0.90 to 2.05 . It is also clear that all the differences are highly significant. The use of the Six Thinking Hats technique in teaching mathematics led to the development of critical thinking skills for the participants of the study. The effect size of this technique was large for all critical thinking skills separately and for the skills combined as a whole. Therefore, the first hypothesis is accepted. To measures the magnitude of the effect of the independent variable on the dependent variable, we used $2 \eta$, which is a two-way correlation between the independent variable and the dependent variable. It is calculated using the following formula: $2 \eta=\frac{2 t}{2 t+D F}$, where DF denotes the number of degrees of freedom (Winer et al., 1991, p.235).

Table 3. Differences in critical thinking between the two groups on the posttest

\begin{tabular}{|c|c|c|c|c|c|c|c|c|c|c|}
\hline \multirow[t]{2}{*}{$\begin{array}{ll}\text { Critical } & \text { Thinking } \\
\text { Skills } & \end{array}$} & \multicolumn{3}{|c|}{$\begin{array}{l}\text { Experimental } \\
\text { Group }\end{array}$} & \multicolumn{3}{|c|}{$\begin{array}{l}\text { Control } \\
\text { Group }\end{array}$} & \multirow[t]{2}{*}{ t-value } & \multirow[t]{2}{*}{$p$-value } & \multirow[t]{2}{*}{$\eta 2$} & \multirow[t]{2}{*}{ ES } \\
\hline & $N$ & Mean & $S D$ & $N$ & Mean & $S D$ & & & & \\
\hline $\begin{array}{lr}\text { Knowledge } & \text { of } \\
\text { assumptions } & \text { and } \\
\text { postulates } & \end{array}$ & 34 & 3.59 & 1.98 & 35 & 2.38 & 1.61 & 3.77 & 0.001 & 0.18 & 0.93 \\
\hline Interpretation & 34 & 3.55 & 0.83 & 35 & 2.29 & 1.07 & 3.65 & 0.001 & 0.17 & 0.90 \\
\hline Deriving & 34 & 5.30 & 0.88 & 35 & 3.83 & 1.52 & 3.98 & 0.001 & 0.19 & 0.97 \\
\hline Deduction & 34 & 5.24 & 0.87 & 35 & 3.75 & 1.16 & 3.88 & 0.001 & 0.18 & 0.93 \\
\hline $\begin{array}{l}\text { Estimating } \\
\text { arguments } \\
\text { discussions }\end{array}$ & 34 & 1.68 & 1.02 & 35 & 0.85 & 1.22 & 3.55 & 0.001 & 0.17 & 0.90 \\
\hline Total & 34 & 19.36 & 4.33 & 35 & 13.10 & 3.39 & 6.60 & 0.001 & 0.39 & 2.05 \\
\hline
\end{tabular}

Note. ES = Effect size

The second hypothesis is that the experimental group has higher levels of numerical sense than the control group at the end of the experiment. Table 4 shows that the hypothesis is strongly confirmed: there are huge differences between groups on all individual measures and also on the total score; the values of the effect size vary from 0.93 to 1.69 . It is also clear that all the differences are highly significant. The use of the Six Thinking Hats technique in teaching mathematics led to the development of critical numerical sense for the participants of the study. The effect size of this technique was large for all numerical sense skills separately and for the skills combined as a whole. Therefore, the second hypothesis is also accepted.

Table 4. Differences in numerical sense between the two groups on the posttest

\begin{tabular}{|l|l|l|l|l|l|l|l|l|l|l|}
\hline \multirow{2}{*}{$\begin{array}{l}\text { Numerical Sense } \\
\text { Skills }\end{array}$} & \multicolumn{2}{|l|}{$\begin{array}{l}\text { Experimental } \\
\text { Group }\end{array}$} & \multicolumn{2}{l|}{$\begin{array}{l}\text { Control } \\
\text { Group }\end{array}$} & & t-value & p-value & $\boldsymbol{\eta} 2$ & ES \\
\cline { 2 - 9 } & $N$ & Mean & $S D$ & $N$ & Mean & $S D$ & & & & \\
\hline $\begin{array}{l}\text { Recognize the } \\
\text { relative impact of } \\
\text { operations on } \\
\text { numbers }\end{array}$ & 34 & 6.87 & 1.14 & 35 & 2.60 & 1.67 & 11.55 & 0.000 & 0.21 & 1.69 \\
\hline $\begin{array}{l}\text { Estimate the results } \\
\text { of mathematical } \\
\text { operations }\end{array}$ & 34 & 6.83 & 1.56 & 35 & 3.30 & 1.82 & 8.07 & 0.001 & 0.18 & 0.93 \\
\hline $\begin{array}{l}\text { Determine the } \\
\text { relationships }\end{array}$ & 34 & 5.25 & 0.88 & 35 & 3.76 & 1.17 & 3.89 & 0.001 & 0.18 & 0.93 \\
\hline
\end{tabular}




\begin{tabular}{|l|l|l|l|l|l|l|l|l|l|l|}
\hline $\begin{array}{l}\text { between macro and } \\
\text { micro groups }\end{array}$ & & & & & & & & & & \\
\hline Total & 34 & 18.95 & 4.10 & 35 & 9.66 & 3.20 & 10.56 & 0.000 & 0.20 & 1.00 \\
\hline
\end{tabular}

Note. ES = Effect size

\section{DISCUSSION}

It is clear that the Six Thinking Hats technique was highly effective in developing critical thinking skills and numerical sense among the study sample, and we will discuss some reasons for this. We will focus first on thinking skills and then on numerical sense. First, the Six Hats technique has focused on linking different kinds of information to each other, which may have helped students understand the relationships between the information and the exercise of critical thinking skills, such as interpretation, classification, discrimination, deduction, conclusion, and evaluation. Second, the Six Hats technique may have promoted the students' motivation to strive for excellence, criticism, creativity, and competition within the classroom. Third, wearing the six hats may have led to a more prominent role for students in the classroom, which may have given them opportunities for excellence, criticism, and practicing different and varied ways of answering. Fourth, it may have helped to make the student free of routine in the educational process, and motivated them to be active, to be participants, and thinkers. Fifth, it may have stimulated competition among students and contributed effectively to attracting their attention, raising their level of ambition, and their continued desire to accomplish other activities.

It should also be noted that many studies have found that critical thinking skills can be developed when teaching mathematics by other approaches, such as: 1) using webquest-based teaching programs to exercise critical thinking (Laing \& Fung, 2020); 2) using the constructivist learning environment on critical thinking ability of the students (Kwan \& Wong, 2015); 3) using elaboration theory (Cakiroglu, 2014; Author, 2015); 4) promoting critical thinking through effective group work (Fung, 2014); 5) including critical thinking skills across the curriculum according to learning outcomes (Thompson, 2011); 6) using practical applications for critical thinking skills during educational psychology courses (Lyutykh, 2009); 7) using explicit and constructivist Mathematics Instruction (Evelyn, et., al., 2004); 8) using a constructivist strategy (Hollenbeck, 2003); and 9) using interdisciplinary algebra-science courses (Elliott, et al., 2001).

What are the reasons that the Six Thinking Hats approach was so effective in developing numerical sense skills? First, it may be that it helped students organize the information they received during the lectures, that it enhanced their meta-cognition, and that it involved them in building their knowledge structures. Second, it may be that it helped the students increase their motivation to participate in all activities, and to employ their various potentials, as those activities and procedures used sensory examples inspired by the students' environment. Third, the Six Hats technique may have worked because it took into account the individual differences between students, which may have helped to motivate them towards learning, achieving, and competing with each other.

It should also be noted that many studies have found that numerical sense skills can also be developed when teaching mathematics by other approaches, such as: 1) using multifactorial approach cognitive skills, language factors, and kindergarten attendance (Aunio et al., 2019); 2) using a strategy based on braincompatible learning theory (Author, 2015); 3) using multimedia based on the theory of multiple intelligences (Abdo, 2013); 4) using a problem-solving method as an approach for the development of numerical sense to pre-school children (Sadek, 2011); 5) using educational games (Khalifa, 2010); 6) using brain-based learning with teacher training (Bello, 2007); and using mathematical activities (Yang, 2003).

This study has several limitations. First of all, the sample sizes are limited but are reasonable when one considers how much time is spent on teaching the children. Many training-related studies show substantially smaller samples. Another limitation is that the children in the sample are not from the affluent regions in Oman or an average region, but from one of the poorer regions of Oman, so the results do not necessarily generalize to other regions. However, one can also argue that when the approach is successful in a region with relatively low investment in education, it might well be at least as successful in regions that spend more on education. 


\section{RECOMMENDATIONS}

Based on the results of this study, the authors recommend that those responsible for developing mathematics curricula should focus on preparing activities and exercises that enable students to practice critical thinking skills and numerical sense, and not only limit themselves to activities and exercises that focus on memorization and knowledge. It is also recommended to consider extending the use of the Six Hats technique to the teaching of all the mathematics courses in secondary education. It is also recommended to consider making a guide for mathematics teachers prepared by the Ministry of Education in Oman widely available, so that interested mathematics teachers can learn the ideas and do not have to start from scratch. In-service mathematics teachers must also be trained to employ modern teaching strategies such as the Six Thinking Hats strategy to develop thinking skills for themselves and their students. Finally, a comparative study on the effect of using the Six Thinking Hats techniques and other techniques on skills and knowledge should be carried out.

\section{REFERENCES}

Abdo, F. (2013). The impact of multimedia in accordance with the multiple intelligences theory to develop the numerical sense skills, and mathematical logic skills at the children's in Riyadh. Journal of Mathematics Education, 14(1), 124- 149.

Abdrabbu, S. (2017). The relative effectiveness of the six thinking hats and Self-Regulated Learning on the development of lateral thinking and achievement motivation in the teaching of mathematics among third grade students. Journal of Mathematics Education, 20 (4), 177- 267.

Abdullatif, A.; Abu Amira, M.\& Setouhi, M. (2014). The effectiveness of a proposed program in algebra based on the six thinking hats in developing creative thinking skills among students of the upper elementary stage. Journal of Scientific Research in Education, 3(15), 291- 328.

Abuasta, F. A. (2011). The effect of multimedia according to multiple intelligences theory on developing numerical sense skills and mathematical logical skills in kindergarten. Journal of Mathematics Education, 14, April, 33- 66.

Ahmed, I. (2016). The effectiveness of using the six thinking hats strategy in developing the mathematical achievement and strength among second grade secondary students. Journal of Mathematics Education, 19 (6), 118- 194.

Alakka, A. (2014). The effectiveness of teaching using the 5e learning cycle and the six thinking hats in developing the skills of solving geometric equations among eighth grade students in Gaza. Master Thesis, Islamic University of Gaza, Palestine.

Alosaimi, K. (2013). The development of critical thinking skills in the science. PhD Thesis, University of Dundee, UK.

Alsaidi, L. (2015). The effectiveness of a program based on the use of six thinking hats in the development of cognitive achievement and mathematical thinking among students of the ninth grade students in the city of Mecca. Journal of Mathematics Education, 18(8), 6- 49.

Alsayyed, R. \& Ahmed, J. (2009). Effectiveness of a proposed design for an environment for learning chemistry compatible with the brain in the development of the habits of mind and achievement of high school students with different information processing methods. Educational and Social Studies, 15(1), 305351.

Aunio, P.; Korhonen, J; Ragpot, L.; Tormanen, M.; Mononen, R. \& Henning, E. (2019). Multifactorial approach to early numeracy- The effects of cognitive skills, language factors and kindergarten attendance on early numeracy performance of South African first graders. International Journal of Educational Research, 97, 65- 76.

Author (2015). European Journal of Social Sciences.

Author (2015). International Journal of Humanities and Cultural Studies.

Badwi, R. (2007). Effective teaching mathematics from kindergarten to sixth grade. Amman, Dar Alfekr.

Bello, D. (2007). The effect of brain-based learning with teacher training in division and fractions in fifth grade students of a private school. Ph.D., Capella University.

Cakiroglu, U. (2014). Implementation of elaboration theory in material design for distance education. Turkish online journal of distance education- TOJDE, 15(1), 143-151.

Carole, G., et.al. (1993). Developing Sense about Numbers. Arithmetic Teacher, 40(5), 279- 284. 
Chrysostomou, M.; Pitta-Pantazi, D.; Tsingi, C.; Cleanthous, E. \& Christou, C. (2013). Examining number sense and algebraic reasoning through cognitive styles. Educational Studies in Mathematics, 83, 205- 223.

Doerr, H. M. (2006). Examining the tasks of teaching when using students' mathematical thinking. Educational Studies in Mathematics, 62, 3-24.

Drijvers, P. D.; Buitenhuis, H. K. \& Doorman, M. (2019). Assessing mathematical thinking as part of curriculum reform in the Netherlands. Educational Studies in Mathematics, 102, 435- 456.

El Mouhayar, R. (2018). Trends of progression of student level of reasoning and generalization in numerical and figural reasoning approaches in pattern generalization. Educational Studies in Mathematics, 99, 89- 107.

Elliott, B.; Oty, K.; Mcarthur, J. \& Clark, B. (2001): The effect of an inter disciplinary algebra-science course on students, problem solving skills, critical thinking skills and attitudes towards mathematics. International Journal of mathematical education in science and technology, 32 (6), 811-816.

Evelyn, H.K.; Joyhannes, E.H.; Vanluit, J. M. \& Cora, J. M. (2004): Effectiveness of explicit and constructivist Mathematics Instruction for low-achieving students in the nether lands. Elementary school Journal, 104(3), 233- 242.

Facione, P. (2011). Critical thinking: What it is and why it counts. Millbrae, CA: California Academic Press.

Fisher, A. (20011). Critical thinking an introduction. Cambridge: University Press.

Freitas, E. \& Sinclair, N. (2016). The cognitive labour of mathematics dis/ability: Neurocognitive approaches to number sense. International Journal of Educational Research, 79, 222- 230.

Fung, D. (2014). Promoting critical thinking through effective group work: A teaching intervention for Hong Kong primary school students. International Journal of Educational Research, 66, 45- 62.

Gocmen, 0. \& Coskum, H. (2019). The effects of the six thinking hats and speed on creativity in brainstorming. Thinking Skills and Creativity, 31, March, 284- 295.

Grissom, R. J. \& Kim, J. J. (2012). Effect Sizes for Research: Univariate and multivariate applications. (2 ${ }^{\text {nd }}$ ed), New York: Routledge.

Habib, A. (2013). The effectiveness of using the six thinking hats strategy on the development of geometric achievement and critical thinking of eight grade students. Journal of Mathematics Education, 16 (4), 179- 227.

Halpern, D. (1996): Thought and knowledge: An introduction to critical thinking. New Jersey: Lawrence Erlbaum Associates publishers.

Hilal, S. (2013). The effectiveness of the six thinking hats strategy in developing some of the mind habits and the achievement of mathematics among tenth grade students. Journal of Arab Studies in Education and Psychology (ASEP), 44 (1), 124-168.

Hollenbeck, J. E. (2003). Using constructivist strategy and methodology to teach science with the Humanities. A paper presented to the third international conference on science, mathematics, and technology education. East London, south Africa, (15-18) January.

Irwin, K. S. \& Britt, M. S. (2005). The algebraic nature of students' numerical manipulation in the New Zealand numeracy project. Educational Studies in Mathematics, 58, 169- 188.

Jordan, N. C.; Glutting, J. \& Ramineni, C. (2010). The importance of number sense to mathematics achievement in first and third grades. Learning and Individual Differences, 20, 82-88. https://doi.org/10.1016/j.lindif.2009.07.004

Khalifa, A. (2010). The Effect of using the educational games in teaching mathematics to development of Achievement and Numerical Sense skills at the third grade students. Master Thesis, College of Educational Studies, Cairo University.

Kharrazah, S. (2016). Using the six thinking hats method in teaching geography to develop cognitive achievement and generative thinking skills in secondary school pupils. Journal of Scientific Research in Education, (17), 577- 593.

Klein, P. S.; Japha, E. A. \& Benizri, S. H. (2010). Mathematical thinking of kindergarten boys and girls: similar achievement, different contributing processes. Educational Studies in Mathematics, 73, 233- 246.

Kwan, Y. W. \& Wong, A. F. (2015). Effects of the constructivist learning environment on Students' critical thinking ability: Cognitive and motivational variables as mediators. International Journal of Educational Research, 70, 68- 79.

Laing, W. \& Fung, D. (2020). Development and evaluation of WebQuest- based teaching performance: Students' use of exploratory talk to exercise critical thinking. International Journal of Educational Research, 104, 101652. 
Lyutykh, E. (2009). Practicing critical thinking in an educational psychology classroom. Journal of educational studies, 45, 377-391.

NCTM (National Council of Teachers of Mathematics) (2014). Principles to actions: ensuring mathematical success for all. Reston, VA: NCTM.

Nieder, A. \& Dehaene, S. (2009). Representation of number in the brain. Annual Review in Neuroscience, 32, 185208.

Nofal, M. (2009). Serious Creativity: Concepts \& Applications, Amman. Amman: De Bono Printing \& Publishing.

Palatnik, A. \& Koichu, B. (2017). Sense making in the context of algebraic activities. Educational Studies in Mathematics, 95, 245- 226.

Pape, S. J.; Bell, C.V. \& Yetkin, I. E. (2003). Developing mathematical thinking and self-regulated learning: A teaching experiment in a seventh-grade mathematics classroom. Educational Studies in Mathematics, 53, 179- 202.

Pinto, G.; Bigozzi, L.; Tarchi, C.; Vezzani, C. \& Accorti G. B. (2016). Predicting reading, spelling, and mathematical skills: A longitudinal study from kindergarten through first grade. Psychological Reports, 118(2), 413440

Purpura, D. J. \& Reid, E. E. (2016). Mathematics and language: Individual and group differences in mathematical language skills in young children. Early Childhood Research Quarterly, 36, 259-268

Rushton, J. (2006). Race differences in intelligence: An evolutionary analysis. Personality and Individual Differences. Retrieved from the EBESCO host database at 12/2/ 2018.

Sadek, E. (2011). Problem-solving method as input for the development of numerical sense to pre-school children. Journal of college of education, Assiut University, 27(1) 308- 363.

Serrat, 0. (2017) Wearing six thinking hats. In: Knowledge Solutions, Springer, Singapore, https://doi.org/10.1007/978-981-10-0983-9_67.

Tamura, Y. \& Furukawa, S. (2007). CSCL environment for "six thinking hats" discussion. In: Apolloni, B.; Howlett, R.J. \& Jain L. (eds) Knowledge-Based Intelligent Information and Engineering Systems, KES 2007, Lecture Notes in Computer Science, Vol (4694), Springer, Berlin, Heidelberg, https://doi.org/10.1007/978-3-540-74829-8_72.

Thompson, C. (2011). Critical thinking across the curriculum: Process over output. International Journal of Humanities and Social Science, 1(9), 1-7.

Volpentesta, A. P.; Muzzupappa, M. \& Ammirato S. (2008) Critical thinking and concept design generation in a collaborative network. In: Camarinha-Matos, L.M. \& Picard, W. (eds) Pervasive collaborative networks, PRO-VE 2008, IFIP - The International Federation for Information Processing, Vol (283), Springer, Boston, MA, https://doi.org/10.1007/978-0-387-84837-2_16.

Wagner, D. \& Davis, B. (2010). Feeling number: grounding number sense in a sense of quantity. Educational Studies in Mathematics, 74, 39- 51.

Winer, B. J., Brown, D. R. \& Michel's, K. M. (1991). Statistical Principles in Experimental Design. (3 ${ }^{\text {rd }}$ ed.), New York: Me Grow Hill.

Yang, D. (2003). Teaching and learning number sense an intervention study of fifth grade students in TAIWAN. International Journal of Science and Mathematics Education, 1(3), 115- 134.

Yang, D. C. (2019). Development of a three-tier number sense test for fifth-grade students. Educational Studies in Mathematics, 101, 405- 424.

Zoller, U. \& Mura, S. (2000). The dispositions toward critical thinking of high school and university science student. An inter- Intra Israel study. International Journal of Science Education. 22(6), 571- 582. 